\title{
TANÁROK EURÓPÁBAN ÉS HAZÁNKBAN
}

A Tempus Közalapítvány az elmúlt években a hallgatói és oktatói mobilitás előmozdítása mellett jelentős szakmai feladatokat is magára vállalt. Ez a misszió elsősorban az Európai Unióban megfogalmazott, kidolgozott szakmai elgondolások, tendenciák hazai közvetítésére vállalkozik. A disszemináció az elmúlt években kitért a pedagógusok képzésének és továbbképzésének számos kérdésére is. Több mühelyt szerveztek a pedagógusképzéssel kapcsolatosan, amelyekben az Európai Unió „Tanárok és trénerek” elnevezésű szakértői munkacsoportjának munkájáról adtak hírt. Ebben a munkacsoportban az elmúlt három évben már hazánk is részt vett. A mühelymunkák rövid ismertetésére és ezen belül az európai uniós javaslatok, következtetések tömör bemutatására vállalkozott az évente megjelenő Mühelybeszélgetések címü kiadvány. A továbbiakban három tanulmányt tárunk az olvasó elé. Az első összefoglalja a Tempus Közalapítványnak a tanárok élethosszig tartó fejlődése érdekében kifejtett tevékenységét. A második az európai uniós szakértői csoport által elemzett fö kérdéseket veszi sorba, és kísérletet tesz a hazai konzekvenciák megfogalmazására. A harmadik tanulmány pedig kiemel ezek közül egyet, a kezdő tanárok bevezető segítésének problémáját, amellyel kapcsolatban az elmúlt hetekben jelent meg egy kézikönyv, és amelynek hazai bevezetése az oktatásügyi kormányzat elodázhatatlan feladata. 